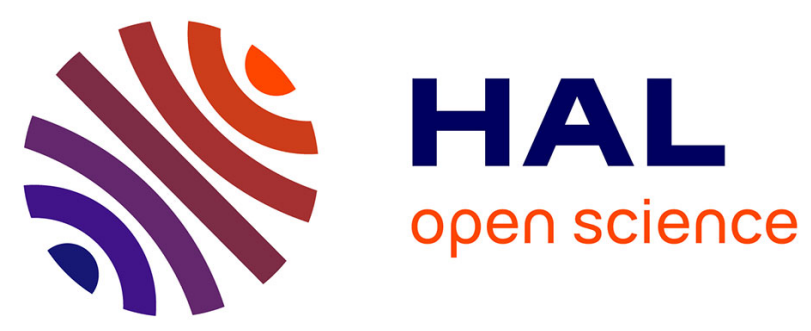

\title{
Synthesis of 3,3-Spirocyclic 2-Phosphonoindolines via a Dearomative Addition of Phosphonyl Radicals to Indoles
}

Dmytro Ryzhakov, Maxime Jarret, Jean-Pierre J.-P. Baltaze, Régis Guillot, Cyrille Kouklovsky, Guillaume Vincent

\section{- To cite this version:}

Dmytro Ryzhakov, Maxime Jarret, Jean-Pierre J.-P. Baltaze, Régis Guillot, Cyrille Kouklovsky, et al.. Synthesis of 3,3-Spirocyclic 2-Phosphonoindolines via a Dearomative Addition of Phosphonyl Radicals to Indoles. Organic Letters, 2019, 21 (13), pp.4986-4990. 10.1021/acs.orglett.9b01516 . hal-02322542

\section{HAL Id: hal-02322542 \\ https://hal.science/hal-02322542}

Submitted on 20 Nov 2020

HAL is a multi-disciplinary open access archive for the deposit and dissemination of scientific research documents, whether they are published or not. The documents may come from teaching and research institutions in France or abroad, or from public or private research centers.
L'archive ouverte pluridisciplinaire HAL, est destinée au dépôt et à la diffusion de documents scientifiques de niveau recherche, publiés ou non, émanant des établissements d'enseignement et de recherche français ou étrangers, des laboratoires publics ou privés. 


\title{
Synthesis of 3,3-Spirocyclic-2-Phosphono-Indolines via a Dearoma- tive Addition of Phosphonyl Radicals to Indoles.
}

\author{
Dmytro Ryzhakov, Maxime Jarret, Jean-Pierre Baltaze, Régis Guillot, Cyrille Kouklovsky and \\ Guillaume Vincent*
}

Institut de Chimie Moléculaire et des Matériaux d’Orsay (ICMMO, UMR 8182), Univ. Paris Sud, Université Paris Saclay, CNRS, 15 rue Georges Clémenceau, 91405 Orsay Cedex, France

Supporting Information Placeholder
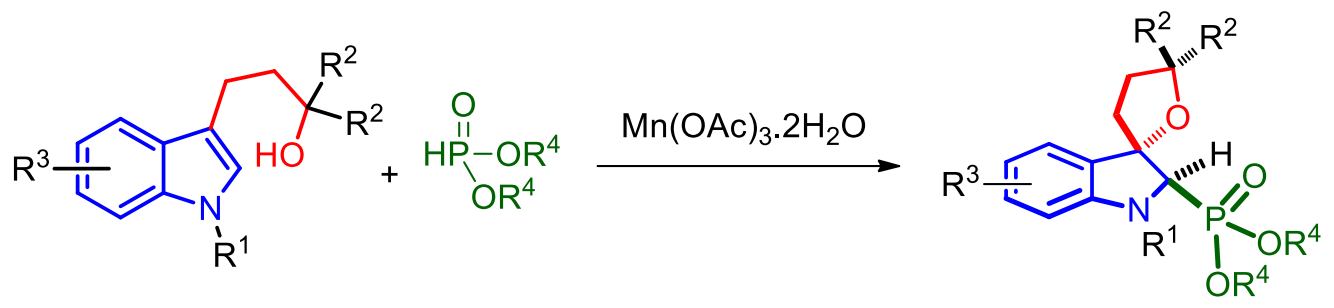

\begin{abstract}
The diastereoselective synthesis of $\alpha$-aminophosphonates derivatives embedded in spirocyclic indolines is reported. The present method proceeds via the dearomative addition of phosphonyl radicals at the $\mathrm{C}_{2}$-position of the indole nucleus in oxidative conditions followed by the intramolecular trapping of the resulting carbocation before rearomatization. trans-3,3-Spirocyclic-2-phosphono-indolines were thus obtained.
\end{abstract}

Dearomatization reactions of indoles ${ }^{1}$ allow to generate three dimensional indoline structures which are of high interest to explore the chemical space and discover compounds of therapeutic potential. ${ }^{2}$ This field has sparked our interest for few years. ${ }^{3}$ We now wish to merge indole dearomatization with phosphorous chemistry and in particular the synthesis of alpha-amino-phosphonate derivatives 1 since the latters display a wide range of biological activities in the field of human health and crop-protection. ${ }^{4}$ alpha-Amino-phosphonic acids are notably considered as bioisosters of the corresponding alpha-amino-carboxylic acids. The tetrahedral geometry of the phosphorous allows alpha-amino-phosphonate derivatives to mimic transition states involved in biological processes which gives unique biological properties to these compounds. Classically, alpha-amino-phosphonates are obtained through the nucleophilic addition of phosphites 2 to imines 3 via the Pudovik reaction or the KabachnikFields reaction from amine 4 and aldehyde 5 (Scheme 1, A). ${ }^{5}$ In few cases, the dearomative addition of phosphorouscontaining nucleophiles to nitrogen-containing electronpoor heteroarenes 6 such as pyridines or quinolines has been reported towards cyclic amino-phosphonates $\mathbf{7}$ (Scheme 1, B). ${ }^{6}$ In line with our research program towards indolines, we were interested to access original alphaamino-phosphonates embedded in an indoline scaffold
10. 7 These compounds would be analogues of indoline-2carboxylic acid derivatives which are relevant in human medicine (Scheme $1, C) .{ }^{8}$ For instance perindopril and trandolapril are commercial drugs to treat blood pressure.

Scheme 1. Radical-mediated dearomative synthesis of 2-phosphono-indolines. 
A. Pudovik and Kabachnik-Fields reactions for the synthesis of $\alpha$-aminophosphonates
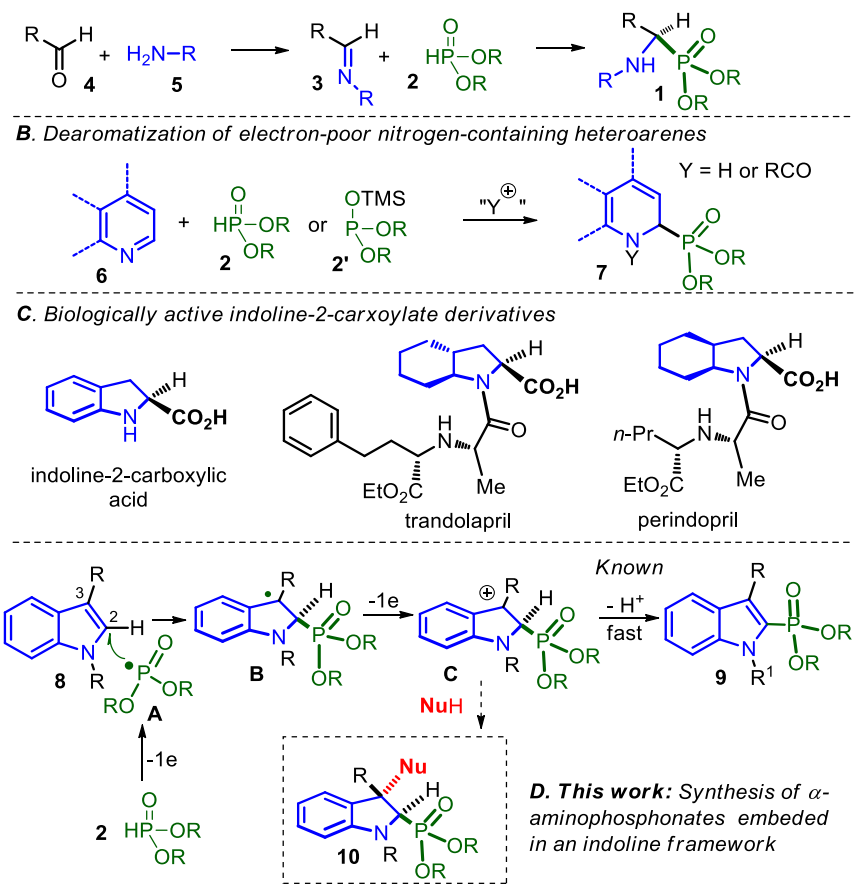

The deployment of a dearomative intermolecular addition of a phosphonyl radical $\mathbf{A}$, resulting from oxidation of $\mathbf{2}$, to the $\mathrm{C}_{2}$-position of indole nucleus $\mathbf{8}$ seems to be an appropriate strategy related to previous radical-mediated dearomatization of indoles. $9^{-11}$ Notably, we described the dearomative synthesis of 2-trifluromethyl-3,3-spiroindoline from the Langlois' reagent (sodium trifluoromethylsulfinate).$^{10}$

Indeed, difunctionalizations of alkenes via the addition of a phosphoryl radical to the double bond are well described..$^{12}$ In the other hand, additions of phosphorus-centred radicals to indoles are known and lead to $\mathrm{C}-\mathrm{H}$ functionalized products 9 after rearomatization of the indole nucleus from carbocation $C$ resulting from the oxidation of the formed radical $\mathbf{B}$ at the $\mathrm{C}_{3}$ position. ${ }^{13,14} \mathrm{After}$ the addition of the radical to the indole at the $\mathrm{C}_{2}$ position, the proton in alpha of the introduced phosphorous atom is believed to be particularly acidic and therefore its elimination should be very fast. Consequently, the interception of the resulting carbocation by a nucleophile before the elimination of this proton and rearomatization of the indole should be especially challenging and is the subject of the present study.

In order to favor the trapping of carbocation $\mathbf{C}$ over the elimination of the proton, we decided to use an intramolecular nucleophile that would lead to 3,3-spiroindolines which are a framework encountered in a large number of biologically relevant molecules. ${ }^{15}$ We evaluated several oxidants which are known to oxidize phosphites into phosphonyl radicals. No reaction was observed with $\mathrm{K}_{2} \mathrm{~S}_{2} \mathrm{O}_{8}$ while $\mathrm{AgNO}_{3}$ with $\mathrm{K}_{2} \mathrm{~S}_{2} \mathrm{O}_{8}$ resulted in the formation of a mixture of unidentified products. The outcome was similar with CAN, which was the optimal oxidant of our previous dearomative trifluoromethylation of indoles..$^{10}$ Only manganese triacetate ${ }^{16}$ proved to be a competent oxidant to produce the desired 3,3-spirocyclic-2-phosphono-indolines 10 as the major product and in each cases, only the trans diastereoisomer was observed. The optimal conditions required to perform the reaction at $80^{\circ} \mathrm{C}$ in acetonitrile during $20 \mathrm{~h}$ with 3 equivalents of $\mathrm{Mn}(\mathrm{OAc})_{3}$ and 5 equivalents of phosphites. The scope of this reaction was then investigated (Scheme 2). The nature of the phosphonyl radical that could be added to N-Boc-3-(3-hydroxypropyl)-indole 8a was first evaluated. We were pleased to note, that dimethyl, diethyl and di-nbutyl phosphites could be employed to synthesize 1oa-c in reasonable yields (41\%, $55 \%$ and $40 \%)$. Remarkably, di-isopropyl phosphite was the optimal phosphorous-containing reagent and delivered $56 \%$ of $10 d$. In general less than $15 \%$ of rearomatized compounds 9 were observed. ${ }^{17}$ Dibenzyl phosphite was also competent to produce 10e in $40 \%$ yield, while more hindered di-tertbutyl and diphenyl phosphites could not allow to isolate the dearomatized product 1of,g. Interestingly, when we employed diphenyl phosphine oxide instead of a phosphite, indoline 10 was obtained in a $13 \%$ yield. The influence of the electron-withdrawing substituent on the indole nitrogen, beside the Boc group (1oa-h) was then scrutinized. Indeed, the ethoxycarbonyl group allow to introduce methyl, ethyl and isopropyl phosphonates in $\mathbf{1 0 i - k}(40 \%, 47 \%, 50 \%)$. This dearomatization also permits the acetyl group to lead to 2-phosphono-indolines 1olo from dimethyl, diethyl, di-nbutyl and di-isopropyl phosphites in respectively $41 \%, 47 \%, 40 \%$ and $50 \%$. The trans relationship between the phosphorous and the oxygen was ascertained through $\mathrm{X}$-ray crystallographic analysis of compound 1ol. A moderate yield of $22 \%$ of 10 pas obtained in presence of the tosyl substituent. The use of a tertiary alcohol in lieu of a primary one as an intramolecular nucleophile efficiently gave rise to spirocyclic indoline $\mathbf{1 0 q}$, whose trans structure was solved by X-ray diffraction of a crystal. ${ }^{18}$

Scheme 2. Synthesis of 3,3-spirocyclic-2-phosphino-indolines. 

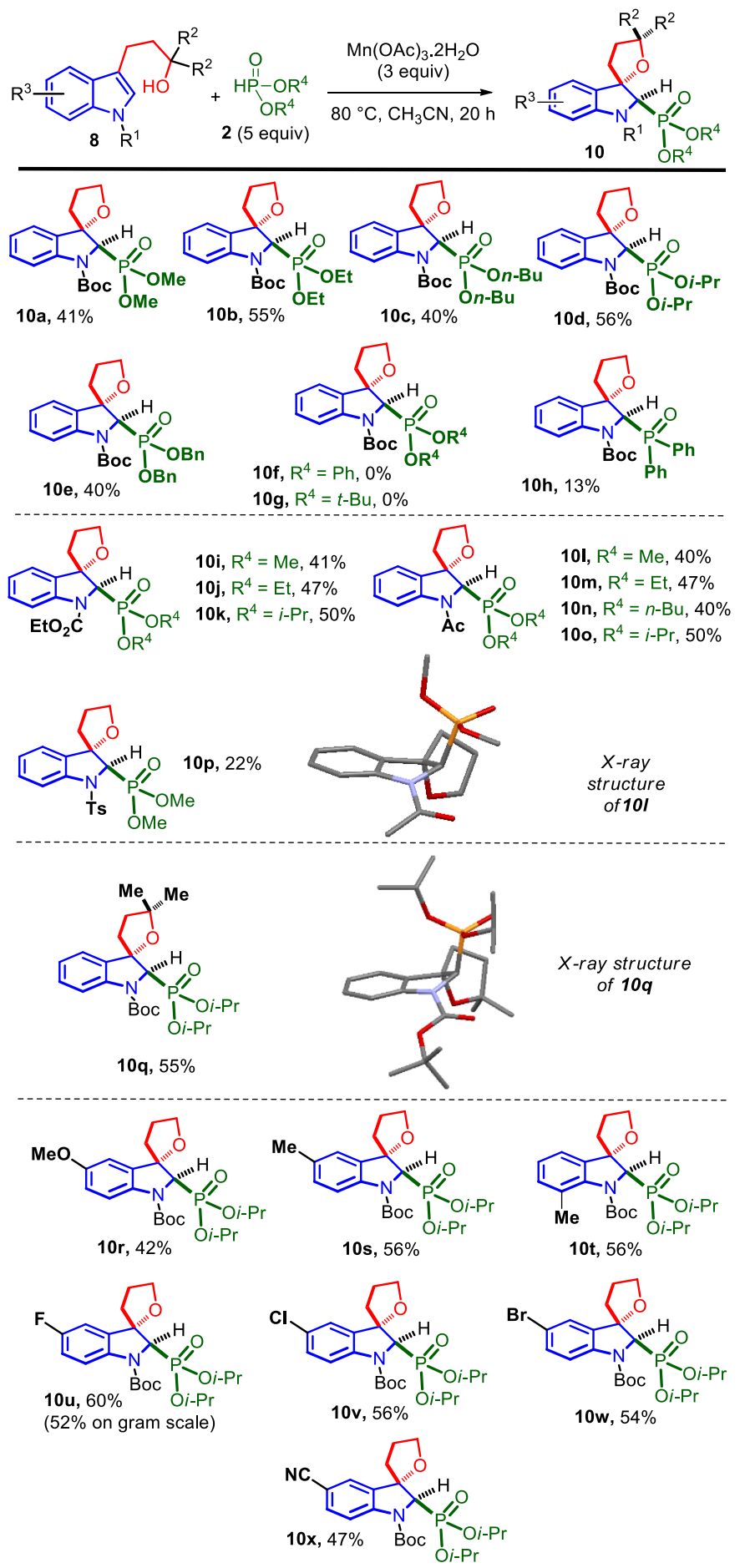

The substitution of the benzene part of the indole was the last point to be studied. The reaction tolerates electron-donating groups such as methoxy at $\mathrm{C}_{5}(\mathbf{1 0 r}, 42 \%)$ and methyl at $C_{5}(10 s, 56 \%)$ and $C_{7}(10 t, 56 \%)$. Halogens could be present during this dearomatization process: 5-fluoro, 5chloro and 5-bromo spirocyclic indolines 1ou-w were obtained in $60 \%, 56 \%$ and $54 \%$ yield. The electron-withdrawing cyano group at the $\mathrm{C}_{5}$ position led to phosphono-indoline 10x in $47 \%$ yield.

As a control experiment, we heated starting indole 8a in presence of 3 equivalents of manganese triacetate during $20 \mathrm{~h}$, without any phosphites and we were able to recover
$55 \%$ of $8 \mathbf{a}$ (Scheme 3). The relative stability of $\mathbf{8 a}$ towards the oxidant seems to exclude a mechanism in which the indole is oxidized into a radical cation followed by the nucleophilic attack of the phosphite and the mechanism depicted in Scheme 1 seems the more plausible. ${ }^{19}$

Scheme 3. Radical-mediated dearomative synthesis of 2-phosphono-indolines.

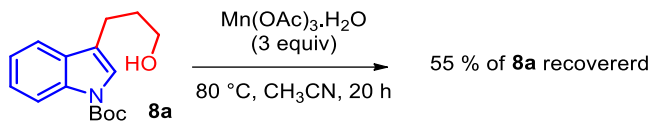

In conclusion, the oxidative coupling between adequately substituted indoles and phosphites in presence of manganese triactate results in the diastereoselective synthesis of trans-3,3-spirocyclic-2-phosphono-indolines via the dearomative addition of a phosphoryl radical to the indole nucleus. Remarkably, the carbocation generated at the $\mathrm{C}_{3}$ position of the indole nucleus could be intramolecularly intercepted in a trans fashion before rearomatization of the indole.

\section{ASSOCIATED CONTENT}

\section{Supporting Information}

The Supporting Information is available free of charge on the ACS Publications website.

Experimental procedures, characterization and NMR spectra of new compounds, copies of NMR spectra. (PDF)

$\mathrm{X}$-ray crystallography analysis data. (cif)

\section{AUTHOR INFORMATION}

\section{Corresponding Author}

* guillaume.vincent@u-psud.fr.

\section{Author Contributions}

The manuscript was written through contributions of all authors. All authors have given approval to the final version of the manuscript.

Notes

The authors declare no conflict of interest.

\section{ACKNOWLEDGMENT}

We thank Prof. Isabelle Chataigner, Dr. Michael De Paolis (Univ. Rouen) and Dr. Xavier Moreau (Univ. Versailles) for helpful discussions. DR thanks the Ministère de l'Enseignement Supérieur, de la Recherche et de l'Innovation (MESRI) for a $\mathrm{PhD}$ fellowship. We also gratefully acknowledge the ANR (ANR-17-CE07-005o; "ArDCo"), Université Paris Sud and the CNRS for financial support.

\section{REFERENCES}

(1) (a) Roche, S. P.; Youte Tendoung, J.-J.; Tréguier, B. Advances in Dearomatization Strategies of Indoles. Tetrahedron 2015, 71, 3549-3591. https://doi.org/10.1016/j.tet.2014.06.054; (b)

Denizot, N.; Tomakinian, T.; Beaud, R.; Kouklovsky, C.; Vincent, G. Synthesis of 3-Arylated Indolines from Dearomatization of Indoles. Tetrahedron Lett. 2015, 56, 4413-4429. https://doi.org/10.1016/j.tetlet.2015.05.078. 
(2) Lovering, F.; Bikker, J.; Humblet, C. Escape from Flatland: Increasing Saturation as an Approach to Improving Clinical Success. J. Med. Chem. 2009, 52, 6752-6756. https://doi.org/10.1021/jmgo1241e.

(3) (a) Wu, J.; Nandi, R. K.; Guillot, R.; Kouklovsky, C.; Vincent, G. Dearomative Diallylation of N-Acylindoles Mediated by $\mathrm{FeCl}_{3}$. Org. Lett. 2018, 20, 1845-1848. https://doi.org/10.1021/acs.orglett.8boo361; (b) Lachkar, D.; Denizot, N.; Bernadat, G.; Ahamada, K.; Beniddir, M. A.; Dumontet, V.; Gallard, J.-F.; Guillot, R.; Leblanc, K.; N'nang, E. O.; et al. Unified Biomimetic Assembly of Voacalgine A and Bipleiophylline via Divergent Oxidative Couplings. Nat. Chem. 2017, 9 (8), 793-798. https://doi.org/10.1038/nchem.2735; (c) Nandi, R. K.; Guillot, R.; Kouklovsky, C.; Vincent, G. Synthesis of 3,3-Spiroindolines via $\mathrm{FeCl}_{3}$-Mediated Cyclization of Aryl- or Alkene-Containing 3-Substituted N-Ac Indoles. Org. Lett. 2016, 18, 1716-1719. https://doi.org/10.1021/acs.orglett.6boo174. (d) Marques, A.-S.; Coeffard, V.; Chataigner, I.; Vincent, G.; Moreau, X. Iron-Mediated Domino Interrupted Iso-Nazarov/Dearomative $(3+2)-\mathrm{Cy}-$ cloaddition of Electrophilic Indoles. Org. Lett. 2016, 18, 52965299. https://doi.org/10.1021/acs.orglett.6bo2613; (e) Nandi, R. K.; Ratsch, F.; Beaud, R.; Guillot, R.; Kouklovsky, C.; Vincent, G. Intermolecular Dearomative C2-Arylation of N-Ac Indoles Activated by $\mathrm{FeCl}_{3}$. Chem. Commun. 2016, 52, 5328-5331. https://doi.org/10.1039/C6CCo1654E; (f) Tomakinian, T.; Guillot, R.; Kouklovsky, C.; Vincent, G. Direct Oxidative Coupling of NAcetyl Indoles and Phenols for the Synthesis of Benzofuroindolines Related to Phalarine. Angew. Chem. Int. Ed. 2014, 53, 1188111885. https://doi.org/10.1002/anie.201404055; (g) Beaud, R.; Guillot, R.; Kouklovsky, C.; Vincent, G. FeCl3-Mediated Friedel-Crafts Hydroarylation with Electrophilic N-Acetyl Indoles for the Synthesis of Benzofuroindolines. Angew. Chem. Int. Ed. 2012, 51, 12546-12550. https://doi.org/10.1002/anie.201206611.

(4) For reviews on biological activities of $\alpha$-aminophosphonates: (a) Kukhar, V. P.; Hudson, H. R. Aminophosphonic and Aminophosphinic Acids: Chemistry and Biological Activity; Wiley, 200o; (b) Orsini, F.; Sello, G.; Sisti, M. Aminophosphonic Acids and Derivatives. Synthesis and Biological Applications. Curr. Med. Chem. 2010, 264-289. https://doi.org/info:doi/10.2174/092986710790149729; $\quad$ (c) Lejczak, B.; Kafarski, P. Biological Activity of Aminophosphonic Acids and Their Short Peptides. In Phosphorous Heterocycles I. Topics in Heterocyclic Chemistry; Bansal, R. K., Ed.; Topics in Heterocyclic Chemistry; Springer Berlin Heidelberg: Berlin, Heidelberg, 2009; pp 31-63. https://doi.org/10.1007/7081 200814.

(5) For reviews on synthesis of of $\alpha$-aminophosphonates: (a) Viveros-Ceballos, J. L.; Ordóñez, M.; Sayago, F. J.; Cativiela, C. Stereoselective Synthesis of $\alpha$-Amino-C-Phosphinic Acids and Derivatives. Molecules 2016, 21, 1141. https://doi.org/10.339o/molecules21091141; (b) Abdel-Rahman, R. M.; Ali, T. E.; Abdel-Kariem, S. M. Methods for Synthesis of N-Heterocyclyl/Heteroaryl- $\alpha$-Aminophosphonates and $\alpha$-(Azaheterocyclyl)Phosphonates. Arkivoc 2016, 183-211. https://doi.org/10.3998/ark.5550190.poog.519; (c) Ordóñez, M.; Viveros-Ceballos, J. L.; Cativiela, C.; Sayago, F. J. An Update on the Stereoselective Synthesis of $\alpha$-Aminophosphonic Acids and Derivatives. Tetrahedron 2015, 71, 1745-1784. https://doi.org/10.1016/j.tet.2015.01.029; (d) Virieux, D.; Volle, J.N.; Pirat, J.-L. Acyclic to Cyclic Aminophosphonic and Phosphinic Acids. Arkivoc 2012, 264-277. https://doi.org/10.3998/ark.5550190.0013.420.

(6) (a) Redmore, D. Phosphorus Derivatives of Nitrogen Heterocycles. I. Preparation and Chemistry of 9,10-Dihydroacridine Phosphonic Acid Derivatives. J. Org. Chem. 1969, 34, 1420-1425. https://doi.org/10.1021/joo1257ao48; (b) Akiba, K.; Negishi, Y.; Inamoto, N. A Facile General Synthesis of Dimethyl 1-Acyl-1,2-Dihydroquinoline-2-Phosphonates and 2-Acyl-1,2-Dihydroisoquinoline-1-Phosphonates. Synthesis 1979, 1979, 55-56. https://doi.org/10.1055/s-1979-28554; (c) Akiba, K.; Matsuoka, H.; Wada, M. Regiospecific Introduction of Alkyl Groups into 4-Position of Pyridine Novel Synthesis of 4-Substituted Pyridines. Tetrahedron Lett. 1981, 22, 4093-4096. https://doi.org/10.1016/So0404039(01)82074-8; (d) Akiba, K.; Kasai, T.; Wada, M. Regioselective Synthesis of 4-Alkylquinolines from Quinoline via 1-Ethoxycarbonyl-1, 2-Dihydroquinoline-2-Phosphonates. Tetrahedron Lett. 1982, 23, 1709-1712. https://doi.org/10.1016/Soo40-4039(00)871968; (e) Haase, M.; Goerls, H.; Anders, E. Synthesis of PO(OR)2- and

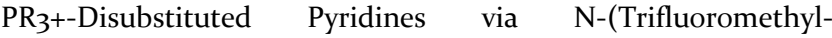
sulfonyl)Pyridinium Triflates. Synthesis 1998, 195-200. https://doi.org/10.1055/s-1998-2012; (f) Clerici, F.; Gelmi, M. L.; Pini, E.; Valle, M. Isothiazoles. Part 12: Isothiazolylphosphonates, a New Class of Isothiazole Dioxides. Tetrahedron 2001, 57, 54555459. https://doi.org/10.1016/Soo40-4020(01)oo448-3; (g) Blieck, A. D.; Masschelein, K. G. R.; Dhaene, F.; Rozycka-Sokolowska, E.; Marciniak, B.; Drabowicz, J.; Stevens, C. V. One-Pot Tandem 1,41,2-Addition of Phosphites to Quinolines. Chem. Commun. 2010, 46, 258-26o. https://doi.org/10.1039/Bgo68o8B; (h) Zhang, Q.; Wei, D.; Cui, X.; Zhang, D.; Wang, H.; Wu, Y. Direct Diphosphonylation of Quinolines with H-Phosphonates under Metal-Free Conditions. Tetrahedron 2015, 71, 6087-6093. https://doi.org/10.1016/j.tet.2015.07.001; (i) Liu, K.; Liu, L.-L.; Gu, C.-Z.; Dai, B.; He, L. Aryne-Induced Dearomatized Phosphonylation of Electron-Deficient Azaarenes. RSC Adv. 2016, 6, 3360633610. https://doi.org/10.1039/C6RAo2128I; (j) Fischer, T. Duong, Q.-N.; García Mancheño, O. Triazole-Based Anion-Binding Catalysis for the Enantioselective Dearomatization of N-Heteroarenes with Phosphorus Nucleophiles. Chem. - Eur. J. 2017, 23, 5983-5987. https://doi.org/10.1002/chem.20160566o.

(7) For the synthesis of related compound via other strategies: (a) Guenther, E.; Hartmann, S.; Noack, H.; Kochmann, W.; Roethling, W. Dietzel, S. (Bitterfeld Chemie) Ger. Dem. Rep. Pat. DD 240373, 1986; (b) Guenther, E.; Ehrhardt, D.; Schmigale, V.; Sourisseau, R. (Bitterfeld Wolfen Chemie) Ger. Offen; Pat. DE 4039752, 1992; (c) Tolmachev, A. A.; Mitrkhin, A. Y.; Tolmacheva, V. S.; Kharchenko, A. V., Khim. Geterotskl. Soedin., 1993, 10491054; (d) Chantegrel, B.; Deshayes, C.; Faure, R. Tandem Wolff Rearrangement-"Tert-Amino Effect" Sequence: Synthesis of 2-Oxoindolinium Enolate and $1 \mathrm{H}-2$-Benzopyrane Derivatives. Tetrahedron Lett. 1995, 36, 7859-7862. https://doi.org/10.1016/o0404039(95)o1636-V; (e) Przychodze, W.; Konitz, A.; Wojnowski, W.; Rachon, J. Reactivity of the Acids of Trivalent Phosphorus and Their Derivatives. Part $\mathrm{X}^{*}$. Unexpected Reactivity of the $>\mathrm{P}_{-} \mathrm{O}^{-}$ Anions Toward 2-Phenyl-3-Phenyliminoindolenine N-Oxide. Phosphorus Sulfur Silicon Relat. Elem. 1998, 132, 21-39. https://doi.org/10.1080/10426509808036971; (f) Arizpe, A.; Sayago, F. J.; Jiménez, A. I.; Ordóñez, M.; Cativiela, C. Stereodivergent Synthesis of Two Novel A-Aminophosphonic Acids Characterised by a Cis-Fused Octahydroindole System. Eur. J. Org. Chem. 2011, 3074-3081. https://doi.org/10.1002/ejoc.201100229; (g) Duncanson, P.; Cheong, Y.-K.; Motevalli, M.; Griffiths, D. V. A Novel Approach to Isoindolo[2,1-a]Indol-6-Ones. Org. Biomol. Chem. 2012, 10, 4266-4279. https://doi.org/10.1039/C2OB25314C; (h) Kamel, A. A.; Geronikaki, A.; Abdou, W. M. Inhibitory Effect of Novel S,N-Bisphosphonates on Some Carcinoma Cell Lines, Osteoarthritis, and Chronic Inflammation. Eur. J. Med. Chem. 2012, 51, 239-249. https://doi.org/10.1016/i.ejmech.2012.02.047; (i) Shaddy, A. A.; Kamel, A. A.; Abdou, W. M. Synthesis, Quantitative Structure-Activity Relationship, and Anti-Inflammatory Profiles of Substituted 5- and 6-N-Heterocycle Bisphosphonate Esters. Synth. Commun. 2013, 43, 236-252. https://doi.org/10.1080/00397911.2011.595603; (j) Zhao, D.; Vásquez-Céspedes, S.; Glorius, F. Rhodium(III)-Catalyzed Cyclative Capture Approach to Diverse 1-Aminoindoline Derivatives at Room Temperature. Angew. Chem. Int. Ed. 2015, 54, 1657-1661. https://doi.org/10.1002/anie.201410342. 
(8) (a) Cleghorn, L. A. T.; Albrecht, S.; Stojanovski, L.; Simeons, F. R. J.; Norval, S.; Kime, R.; Collie, I. T.; De Rycker, M.; Campbell, L.; Hallyburton, I.; et al. Discovery of Indoline-2-Carboxamide Derivatives as a New Class of Brain-Penetrant Inhibitors of Trypanosoma Brucei. J. Med. Chem. 2015, 58, 7695-7706. https://doi.org/10.1021/acs.jmedchem.5boo596; (b) Hayashi, S.; Ohashi, K.; Mihara, S.; Nakata, E.; Emoto, C.; Ohta, A. Discovery of Small-Molecule Nonpeptide Antagonists of Nociceptin/Orphanin FQ Receptor: The Studies of Design, Synthesis, and Structure-Activity Relationships for (4-Arylpiperidine Substituted-Methyl)-[Bicyclic (Hetero)Cycloalkanobenzene] Derivatives. Eur. J. Med. Chem. 2016, 114, 345-364. https://doi.org/10.1016/j.ejmech.2016.02.014.

(9) (a) Li, J.; Liu, M.; Li, Q.; Tian, H.; Shi, Y. A Facile Approach to Spirocyclic 2-Azido Indolines via Azidation of Indoles with Ceric Ammonium Nitrate. Org. Biomol. Chem. 2014, 12, 9769-9772. https://doi.org/10.1039/C4OBo1549E; (b) Ye, J.-H.; Zhu, L.; Yan, S.-S.; Miao, M.; Zhang, X.-C.; Zhou, W.-J.; Li, J.; Lan, Y.; Yu, D.-G. Radical Trifluoromethylative Dearomatization of Indoles and $\mathrm{Fu}-$ rans with $\mathrm{CO}_{2}$. ACS Catal. 2017, 7, 8324-8330. https://doi.org/10.1021/acscatal.7bo2533.

(10) Ryzhakov, D.; Jarret, M.; Guillot, R.; Kouklovsky, C.; Vincent, G. Radical-Mediated Dearomatization of Indoles with Sulfinate Reagents for the Synthesis of Fluorinated Spirocyclic Indolines. Org. Lett. 2017, 19, 6336-6339. https://doi.org/10.1021/acs.orglett.7bo3155.

(11) For trapping of the carbocation at $\mathrm{C}_{3}$ by a nucleophile tethered to the radical precursor: (a) Benkovics, T.; Guzei, I. A.; Yoon, T. P. Oxaziridine-Mediated Oxyamination of Indoles: An Approach to 3-Aminoindoles and Enantiomerically Enriched 3-Aminopyrroloindolines. Angew. Chem. Int. Ed. 2010, 49, 9153-9157. https://doi.org/10.1002/anie.201004635; (b) Gao, Y.; Fan, M.; Geng, Q.; Ma, D. Total Synthesis of Lapidilectine B Enabled by Manganese(III)-Mediated Oxidative Cyclization of Indoles. Chem. Eur. J. 2018, 24, 6547-6550. https://doi.org/10.1002/chem.201801312 and ref 3f; for the synthesis of spiroindolines via the dearomative intramolecular addition of a radical at $C_{3}$ : (c) Wang, Q.; Qu, Y.; Xia, Q.; Song, H.; Song, H.; Liu, Y.; Wang, Q. Synthesis of Gem-Difluorinated Spiro- $\gamma$-Lactam Oxindoles by Visible-Light-Induced Consecutive Difluoromethylative Dearomatization, Hydroxylation, and Oxidation. Chem. Eur. J. 2018, 24, $11283-11287$. https://doi.org/10.1002/chem.201802141.

(12) For a review: (a) Gao, Y.; Tang, G.; Zhao, Y. Recent Progress toward Organophosphorus Compounds Based on PhosphorusCentered Radical Difunctionalizations. Phosphorus Sulfur Silicon Relat. Elem. 2017, 192, 589-596. https://doi.org/10.1080/10426507.2017.1295965; for selected examples: (b) Wei, W.; Ji, J.-X. Catalytic and Direct Oxyphosphorylation of Alkenes with Dioxygen and H-Phosphonates Leading to $\beta$ Ketophosphonates. Angew. Chem. Int. Ed. 2011, 50, 9097-9099. https://doi.org/10.1002/anie.201100219; (c) Pan, X.-Q.; Wang, L.; Zou, J.-P.; Zhang, W. Manganese(III)-Mediated Phosphinoyl Radical Reactions for Stereoselective Synthesis of Phosphinoylated Tetrahydronaphthalenes. Chem. Commun. 2o11, 47, 7875-7877. https://doi.org/10.1039/C1CC12343B; (d) Zhang, C.; Li, Z.; Zhu, L.; Yu, L.; Wang, Z.; Li, C. Silver-Catalyzed Radical Phosphonofluorination of Unactivated Alkenes. J. Am. Chem. Soc. 2013, 135, 1408214085. https://doi.org/10.1021/ja408031s; (e) Gao, Y.; Wu, J.; Xu, J.; Zhang, P.; Tang, G.; Zhao, Y. Mn(OAc)3-Mediated Synthesis of $\beta$ Hydroxyphosphonates from $\mathrm{P}(\mathrm{O})-\mathrm{H}$ Compounds and Alkenes. RSC Adv. 2014, 4, 51776-51779. https://doi.org/10.1039/C4RA10593A; (f) Zhou, S.-F.; Li, D.-P.; Liu, K.; Zou, J.-P.; Asekun, O. T. Direct Radical Acetoxyphosphorylation of Styrenes Mediated by Manganese(III). J. Org. Chem. 2015 8o, 1214-1220. https://doi.org/10.1021/j05023298; (g) Gao, Y.; Li, X.; Xu, J.; Wu, Y.; Chen, W.; Tang, G.; Zhao, Y. Mn(OAc)3-Mediated
Phosphonation-Lactonization of Alkenoic Acids: Synthesis of Phosphono- $\gamma$-Butyrolactones. Chem. Commun. 2015, 51, 16051607. https://doi.org/10.1039/C4CCo7978G; (h) Xu, J.; Li, X.; Gao, Y.; Zhang, L.; Chen, W.; Fang, H.; Tang, G.; Zhao, Y. Mn(III)Mediated Phosphonation-Azidation of Alkenes: A Facile Synthesis of $\beta$-Azidophosphonates. Chem. Commun. 2015, 51, 11240-11243. https://doi.org/10.1039/C 5 CC03995A; (i) Li, C.-X.; Tu, D.-S.; Yao, R.; Yan, H.; Lu, C.-S. Visible-Light-Induced Cascade Reaction of Isocyanides and N-Arylacrylamides with Diphenylphosphine Oxide via Radical C-P and C-C Bond Formation. Org. Lett. 2016, 18, 4928-4931. https://doi.org/10.1021/acs.orglett.6bo2413; (j) Xu, J.; Yu, X.; Song, Q. Silver-Catalyzed Radical-Involved Cascade Cyclization of Diphenylphosphine with Cinnamamides: Access to 2Phosphinoyl-3H-Pyrrolo[1,2-a]Indoles. Org. Lett. 2017, 19, 980983. https://doi.org/10.1021/acs.orglett.6bo3713; (k) Zhang, P.-Z.; Zhang, L.; Li, J.-A.; Shoberu, A.; Zou, J.-P.; Zhang, W. Phosphinoyl Radical Initiated Vicinal Cyanophosphinoylation of Alkenes. Org. Lett. 2017, 19, 5537-5540. https://doi.org/10.1021/acs.orglett.7bo2621; (1) Tao, Z.-K.; Li, C.-K.; Zhang, P.-Z.; Shoberu, A.; Zou, J.-P.; Zhang, W. Phosphinoyl Radical-Initiated 1,2-Bifunctional Thiocyanodiphenylphosphinoylation of Alkenes. J. Org. Chem. 2018, 83, 2418-2424. https://doi.org/10.1021/acs.joc.7bo2929; (m) Wang, Y.; Wang, W.; Tang, R.; Liu, Z.; Tao, W.; Fang, Z. Iron(III)-Catalyzed Radical $\alpha, \beta$ Aminophosphinoylation of Styrenes with Diphenylphosphine Oxides and Anilines. Org. Biomol. Chem. 2018, 16, 7782-7786. https://doi.org/10.1039/C8OBo2151A

(13) (a) Wang, H.; Li, X.; Wu, F.; Wan, B. Direct Oxidative C-P Bond Formation of Indoles with Dialkyl Phosphites. Synthesis 2012, 44, 941-945. https://doi.org/10.1055/s-0031-1289700; (b) Yadav, M.; Dara, S.; Saikam, V.; Kumar, M.; Aithagani, S. K.; Paul, S.; Vishwakarma, R. A.; Singh, P. P. Regioselective Oxidative C-H Phosphonation of Imidazo[1,2-a]Pyridines and Related Heteroarenes Mediated by Manganese(III) Acetate. Eur. J. Org. Chem. 2015, 6526-6533. https://doi.org/10.1002/ejoc.201500984; (c) Sun, W.-B.; Xue, J.-F.; Zhang, G.-Y.; Zeng, R.-S.; An, L.-T.; Zhang, P.-Z.; Zou, J.-P. Silver-Catalyzed Direct $\mathrm{C}_{\mathrm{sp2}}-\mathrm{H}$ Phosphorylation of Indoles Leading to Phosphoindoles. Adv. Synth. Catal. 2016, 358, 1753-1758. https://doi.org/10.1002/adsc.201600oo1; (d) Zhao, Z.; Min, Z.; Dong, W.; Peng, Z.; An, D. Photoredox Catalyst-Mediated Direct Regioselective Phosphonylation of Indoles. Synth. Commun. 2016, 46, 128-133 https://doi.org/10.108o/00397911.2015.1122807. (e) Shaikh, R. S.; Ghosh, I.; König, B. Direct C-H Phosphonylation of Electron-Rich Arenes and Heteroarenes by Visible-Light Photoredox Catalysis. Chem. - Eur. J. 2017, 23, 12120-12124. https://doi.org/10.1002/chem.201701283.

(14) For a review on the synthesis of phosphorous-containing indole derivatives: (a) Chen, L.; Zou, Y.-X. Recent Progress in the Synthesis of Phosphorus-Containing Indole Derivatives. Org. Biomol. Chem. 2018, 16, 7544-7556. https://doi.org/10.1039/C8OBo210oG; for a review on direct phosphonylation of aromatic azaheterocycles: (b) Jeught, S. V. der; Stevens, C. V. Direct Phosphonylation of Aromatic Azaheterocycles. Chem. Rev. 2009, 109, 2672-2702. https://doi.org/10.1021/cr8oo315j.

(15) For reviews: James, M. J.; O’Brien, P.; Taylor, R. J. K.; Unsworth, W. P. Synthesis of Spirocyclic Indolenines. Chem. - Eur. J. 2016, 22, 2856-2881. https://doi.org/10.1002/chem.201503835.

(16) Mondal, M.; Bora, U. Recent Advances in Manganese(III) Acetate Mediated Organic Synthesis. RSC Adv. 2013, 3 , 18716-18754. https://doi.org/10.1039/C3RA4248oD. (b) Snider, B. B. Manganese(III)-Based Oxidative Free-Radical Cyclizations. Chem. Rev. 1996, 96, 339-364. https://doi.org/10.1021/cr950026m.

(17) In general, we also observed products arising from the addition of radical A onto the benzene part of compounds $\mathbf{9}$. 
(18) Replacing the terminal alcohol on the $\mathrm{C}_{3}$-side chain by a tosyl amide (NHTs) or using di-N,N'-Ac-tryptamine only led to rearomatized products of type $\mathbf{9}$ after the addition of the phosphonyl radical.

(19) To operate in the absence of an intramolecular nucleophile, we used N-Boc-3-methylindole in the classical reaction conditions of scheme 2 with di-isopropyl phosphite. We observed the formation of compound $9 y$ as well as products arising from the addition of radical $\mathbf{A}$ onto the benzene part of compounds 9y (see footnote 17). We did not observed a Ritter type reaction with the trapping of carbocation $\mathbf{C}$ by acetonitrile. 